\title{
IS FALISCAN A LOCAL LATIN PATOIS?*
}

\author{
BRIAN D. JOSEPH \& REX E. WALLACE \\ The Ohio State University \& The University of Massachusetts
}

\section{Introduction}

The question of the position of Faliscan with respect to other ancient languages of Italy, especially Latin, Oscan, and Umbrian, has received several different answers in the literature. The traditional view ${ }^{1}$ is that Latin and Faliscan together form a subgroup, LatinoFaliscan, within Italic ${ }^{2}$ opposed to an Oscan-Umbrian subgroup. ${ }^{3}$ Thus, in this view, Faliscan is considered to be a language separate from Latin but closely linked to it--in fact its closest relative--as Latin's most immediate sibling in the Italic family tree, as illustrated in $(1):^{4}$

$\begin{array}{lll} & \text { I } & \text { Italic } \\ \text { Latino-Faliscan } & \text { Oscan-Umbrian } \\ \text { Latin } & \text { Faliscan } & \begin{array}{r}\text { Oscan, Umbrian, South Picene, } \\ \text { / I । } \\ \text { Votin, Roman Latin, ... }\end{array}\end{array}$

${ }^{*}$ A version of this paper was read before the panel of the Greek and Latin Linguistics Association at the annual meeting of the American Philological Association in December 1990. We express our appreciation to Philip Baldi, H. Craig Melchert, James Poultney, Donald Ringe, Jr., Brent Vine, and an anonymous reader for their helpful comments.

Boldface type is used for words written in the native Faliscan, Oscan, Umbrian, South Picene, and Etruscan alphabets. We employ the following abbreviations: CIE = Corpus Inscriptionum Etruscarum; $\mathrm{CIL}=$ Corpus Inscriptionum Latinarum $; \mathrm{D}=$ Degrassi 1957; GG = Giacomelli 1963; GLK = Keil 1880; MA = Marinetti 1985; TLE = Pallottino 1968; VE = Vetter 1953.

${ }^{1}$ On the notion Latino-Faliscan see Buck (1933:24); Cowgill (1986:36); Diver (1953:171); Leumann-Hofmann-Szantyr (1972:27*-28*); Sommer-Pfister (1977:10, 12-14).

2 For discussion of Italic as a subgroup of Indo-European, see Cowgill (1986:34-38); Diver (1953); Leumann-Hofmann-Szantyr (1972:10*, 21*); Meillet (1933:48-72); MeilletVendryes (1953:11, 13-14); Meiser (1986:37-38); Poultney (1959:7-9); Sommer-Pfister (1977:4-5). For the position of Venetic, which is often considered an Italic language, see Polomé (1966:71-76) and Cowgill (1986:56-57 with references).

3 The most recent investigation of Oscan-Umbrian unity is Meiser (1986:16-17, 39-107). Additional details concerning the interrelationships within Oscan-Umbrian are discussed in Adiego Lajara (1990), Marinetti (1985:32-46), Meiser (1987), and Wallace (1985).

4 According to this view, divergence between Latin and Faliscan had to have taken place at some point before the late Iron age, surely well before the 7th century when the earliest

Faliscan and Latin inscriptions are attested. See Leumann-Hofmann-Szantyr (1972:27*). 
A somewhat idiosyncratic view is that given by Beeler 1956:48 (later recanted in Beeler 1963:57 but suggested also by Campanile 1968:107), in which Faliscan belongs to a branch of Proto-Italic that is distinct from the Latin branch and from the Oscan-Umbrian branch, as illustrated in (2):

(2)

\begin{tabular}{|c|c|c|c|}
\hline \multicolumn{4}{|c|}{ Italic } \\
\hline & / & I & 1 \\
\hline Latin & & Faliscan & Oscan-Umbrian \\
\hline I & 1 & & l \\
\hline
\end{tabular}

Praenestine Latin , Roman Latin, ... Oscan, Umbrian, South Picene, Volscian, Paelignian, Marrucinian, ...

Finally, there is a view in which Faliscan is treated as a regional variety of Latin on a par, from a dialectological point of view, with the Latin of Rome or of Praeneste. ${ }^{5}$ This is illustrated in (3):

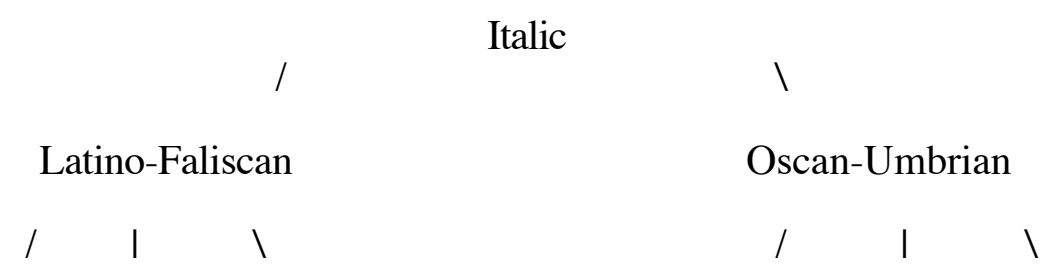

Faliscan Praenestine Latin Roman Latin ... Oscan, Umbrian, South Picene, Volscian, Paelignian, Marrucinian, ...

Of these three positions, the one that has attracted the most attention in recent years is the third one. Focussing on certain phonological and morphological features that Faliscan and regional varieties of Latin outside of the city Rome have in common, proponents of this view have assumed that Faliscan is a regional dialect of Latin, no different in the relevant sense from the Latin of Rome, the Latin of Praeneste, or the Latin of Tibur, etc.

In this paper, however, we challenge and ultimately repudiate this view by showing that the features offered as evidence for the position of Faliscan as a regional variety of Latin are not at all probative with regard to the position of Faliscan vis-à-vis Latin. Further, we offer some evidence not previously adduced in this context to show that there are chronologically early innovative changes in Faliscan and in Latin that are not shared between the two, and that consequently point to their being two separate languages, standing in the traditionally assumed relationship given in (1) above.

\section{Methodological Considerations}

${ }^{5}$ See Beeler (1963:57-58); Campanile (1961:1-21); Conway (1897:287); Eska (1987:150); Giacomelli (1979:151); Maniet (1972:524); Palmer (1954:59); Pisani (1962:57); Pulgram (1978:163). 
There are several methodological considerations that need to be addressed as preliminaries to this study. First and foremost among them is the matter of terminology.

We have so far been referring to 'Latin', 'Faliscan', and 'dialect of Latin' without making precise just what these terms mean. As it happens, there are many different uses of these terms 6 in the literature on Latin, especially 'Latin' and 'dialectal Latin', that potentially confound the issue of the place within the linguistic spectrum of ancient Italy of the language spoken by the inhabitants of the settlement known as Falerii Veteres and its immediately surrounding territory (Giacomelli 1963:24). For instance, Sittl (1882:38) essentially distinguishes between the Latin spoken in Latium and that spoken in territory outside of Latium, whereas Ernout (1909:30-35) considers 'dialectal' that part of the Latin lexicon which was introduced from nonlearned and/or nonliterary sources; thus, for Ernout, words borrowed from Greek literary and learned sources do not count as 'dialectal' inasmuch as they formed part of the active competence of the Roman intelligentsia. A distinction between 'rustic' or 'country' Latin on the one hand and 'urban' Latin on the other appears in, for instance, the work of Giacomelli (1979:151), Meillet (1933:99-101), Meillet \& Vendryes (1953:11), Palmer (1954:59), Sommer-Pfister (1977:8), and such a distinction appears to have been recognized by Roman Latin speakers themselves (see Cicero de Or. 3, 12, 44; de Or. 3, 11, 42; Brut. 36, 137; Brut. 74, 259). ${ }^{7}$ However, the notion of 'rural' or 'rustic' Latin as a general cover term for dialectal features not found in Roman Latin ${ }^{8}$ is misguided--or, at the very least, is a misnomer--since it implies that Latium was throughout its history without other important municipalities, and this is demonstrably not the case. ${ }^{9}$ We therefore reserve the terms 'rustic' or 'rural' for just those instances in which an ancient authority such as Varro used the corresponding Latin term to describe some lexical item or grammatical feature. 10

Given the potential for confusion with these terms, we herein use the term 'Latin' to take in all varieties of the language spoken in ancient times in Latium and in colonies

6 A sampling of the various terms used in discussion of the dialects of Latin can be found in the following sources: Buck (1933:26); Campanile (1961:1-2); Conway (1897:287); Ernout (1909:15-29); Leumann-Hofmann-Szantyr (1972: 28*); Meillet (1933: 94-95); MeilletVendryes (1953:11); Palmer (1954: 59); Risch (1979:705); Schmid (1965:200); Sittl (1882:38); Sommer-Pfister (1977:8); Wachter (1987:101-02). The issue of the various uses of these terms is one which we intend to address more fully in a future study.

${ }^{7} \mathrm{We}$ are also willing to believe that various apparent dialectal features, e.g. labials from PIE labiovelars (bos "ox" <* $\mathrm{gW}^{\mathrm{Ou}}$ rather than expected *u>us), $\underline{l}$ from PIE $* \mathrm{~d}$ (leuir "brotherin-law" <*daiH2u>er rather than expected *daeuer), may be characteristic of Latin spoken in the countryside--the problem lies in the fact that there is no way to independently corroborate the rural status of these features.

${ }^{8}$ The terms 'urban' Latin and 'rural' Latin undoubtedly reflect a view of Latin whose focus is Rome, the most important urban center in Latium (and Italy), but we want to dissociate ourselves from such a view because of its potentially confusing or inaccurate implications.

${ }^{9}$ We recognize the inherent difficulty in applying modern terms like city, town, etc. in these cases, but our point is that the label 'rural' is not suitable for Praeneste, Tibur, and other important settlements in Latium from the 4th century on.

10 We also recognize that other descriptors used by ancient authorities, such as 'antiqui dicebant ...', may well point to real dialectal Latin features. For example, the word nefrundines "kidneys" is attributed by Festus $(342,35 \mathrm{~L})$ to the 'antiqui'. In Paulus (157, 9L), however, etymologically related forms (though with the meaning "testicles") are given dialectal status, e.g. nebrundines [Lanuvium], nefrones [Praeneste]. 
sponsored by Rome and by other communities of Latium. In this way, our use of 'Latin' is similar to conventional use of a language name such as 'English' in most linguistic writings. We further distinguish, then, between, the Latin of Rome (Sommer(-Pfister)'s (1977:8) 'Stadtrömisch' or Buck's (1933:26) 'language of city Rome') and of other areas, e.g. Praenestine Latin, and reserve the term 'dialectal Latin' in general for non-Roman Latin. The term 'Faliscan', since the language was spoken only in a rather restricted area geographically, can continue to be used as such--even if it should turn out to be a 'dialect of Latin' sensu stricto.

The second aspect of methodology which we feel is essential to make explicit is the principles by which languages and dialects are subgrouped. These principles are wellknown in historical linguistics and dialectological studies, as best embodied in the presentation of Hoenigswald (1960), but they bear reiteration here so that the ground rules for the remaining discussion are established.

First of all, a linguistic feature shared between two (or more) related languages is evidence for subgrouping only if that feature is a shared innovation, not a shared retention from their common source. Further, that feature must be one that is not so 'natural'11 that it is likely to have arisen independently more than once.

But even shared innovations need not be indicative of an original linguistic unity. They could reflect the areal spread of changes after considerable divergence of the two languages had taken place. When considering innovations, then, it is crucial also to consider their chronology. Only innovations that can be shown to have occurred before divergence count for determining the subgrouping of related languages.

More generally, although the Stammbaum model for describing the origin of linguistic diversity is often opposed to the Wave model for spread of innovations, we see no contradiction between the two models. Rather we note that for the wave model to be successful in any particular case, the social conditions for the wave-like diffusion of an innovation across speech communities would have to be met.

A third methodological issue relevant here is the chronology of Faliscan. Three main periods, based on epigraphical evidence, are commonly assumed for Faliscan (Giacomelli 1978:510-511): Archaic Faliscan [AF] covering the 7th/6th centuries B.C., Medio-Faliscan $[\mathrm{MF}]$ ranging from the 5th century B.C to the destruction of Falerii veteres by the Romans in 241 B.C., and Neo-Faliscan [NF] taking in all inscriptions composed after the relocation of the inhabitants of Falerii veteres to Falerii novi, a much less formidable site a few miles to the west. It is clear, then, that for the purposes of determining the position of Faliscan within Italic, features from Archaic or Medio-Faliscan would be the most revealing, for any Latinate features found in Neo-Faliscan could very well have resulted from the increasing Romanization of Faliscan speakers after 241 B.C.

Finally, a further problem, endemic to all studies involving 'Restsprache' like Faliscan, is that there is actually very little evidence to work from. Giacomelli (1963) lists 150 Faliscan inscriptions, and there are a few others which might be added to the corpus (see Renzetti Marra 1974:350-351); most, however, are very short and the majority of them are funerary in nature. As a result, the greater portion of the evidence consists of

11The term 'natural' is itself fraught with potential ambiguities that make it hard to use in a precise way. One could take the view that anything that occurs even once in the history of some human language is 'natural' in that it lies within the range of possibilities for some natural language; alternatively, one might be more restrictive and insist that only a frequently encountered change or feature would qualify as 'natural'. The problem in the latter case, however, is that it is difficult to establish a numerical threshold for 'naturalness' defined in this way. We leave this question open. 
onomastica, not always a very fruitful source of data for the task at hand; still, the available evidence can be used, if it is used judiciously.

\section{Faliscan as a Local Latin Patois?}

To turn now to the evidence adduced in support of the position that Faliscan is a regional dialect of Latin, we give below, without necessarily endorsing, a list of various features that have been proposed in the literature. These generally represent features that are attested in Faliscan inscriptions and in Latin inscriptions found outside of the city Rome.

The features presented below are taken in large part from those discussed in Campanile (1961) and Eska (1987). We have made some editorial changes, mainly in the area of formatting, so that the list of Faliscan and putative dialectal Latin examples is more easily comparable. But we have made no attempt to eliminate forms given by Campanile and Eska on the grounds that they are not relevant, despite the fact that we recognize this to be so in several instances. ${ }^{12}$

For each such feature presented below, we give first an identifying label, then in (a) and (b) a representative list of the Faliscan and the non-Roman Latin forms respectively that document the occurrence of said feature (note that examples are not always available from each of these speech communities to illustrate each feature fully). ${ }^{13}$ By way of contrast, we give in addition corresponding forms from the Latin of Rome--inscriptional (CIL ${ }^{2}$ ), where available, otherwise literary--after relevant entries. To make the comparison as clear as possible, we give an indication of the etymological source of the feature where appropriate.

(4) Monophthongization *ai $>\underline{e}, * \mathrm{ei}>\underline{e}, * \mathrm{oi}>\underline{Q}, * \mathrm{au}>\underline{o}, * \mathrm{ou}>\underline{o}$

a. efiles NOM PL "aediles [magistrates of public works]" GG 15 (*aidh-), cf. Roman Latin aediles CIL I², 37

hec "here" GG 121.IIb (Proto-Italic *xei-ke), cf. Roman Latin hic

loferta "freedwoman" GG 121.I (*loif-, cf. MF loifirtato, from Proto-Italic

*leu†-, PIE * $\mathrm{H}_{1}$ leudh-), cf. Roman Latin liberta

pola feminine praenomen GG 74, cf. Roman Latin [p]aulla CIL I², 16

b. cesula feminine praenomen CIL $\mathrm{I}^{2}, 376$ [Pisaurum], cf. caesula esculapio DAT SG Aesculapius [deity] CIL 14, 2846 [Praeneste], cf. Roman Latin aiscolapio DAT SG CIL I², 26

12 For example, some forms found in inscriptions coming from Roman/Latin citizen colonies could contain substratum influences and thus not reflect original dialectal Latin characteristics (e.g., monophthongization cesula feminine praenomen CIL $1^{2}, 376$ [Pisaurum in Umbrian territory], cf. Roman Latin caesula). Other forms do not securely show the feature they are intended to show. For example, matrona pisaurese CIL $1^{2}, 378$ is cited as an example of the loss of $-s$ after long vowels. However, only pisaurese can be an example of this change. matrona NOM PL is best interpreted as a writing for *matronai (Wachter 1987:435-436). Moreover, matrona pisaurese should be used with some caution since the right edge of the inscription on which these words are found is broken off and the final letters at the ends of these words could have been lost.

${ }^{13}$ Faliscan and dialectal Latin forms are cited as found in inscriptions. Unless otherwise noted, all nominal forms are nominative singular and all verbal forms are third person singular present. Note that Latin forms are cited without indication of vowel length, following standard Roman orthographical practices. 
$\underline{\text { edus }}$ "goat" [Varro, L.L. . 5, 97] (*ghaid-, cf. Eng. goat), cf. Roman Latin haedus

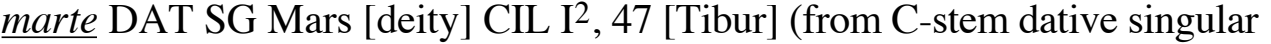

*-ei), cf. Roman Latin DAT SG martei CIL 12, 609

hercole DAT SG Hercules [deity] CIL I ${ }^{2}, 61$ [Praeneste] (from C-stem dative singular *-ei), cf. Roman Latin DAT SG hercolei CIL I², 607

coraueron 3PL PERF "administered" CIL 12, 59 [Praeneste] (cf. Paelignian coisatens 3PL PERF VE 214), cf. Roman Latin 3PL PERF curauerunt

plotia feminine praenomen CIL XIV, 3369 [Praeneste], cf. Roman Latin plautia losna "moon" CIL I², 549 [Praeneste] (*louk-sn`a), cf. Roman Latin luna poloces Pollux [deity] CIL I ${ }^{2}, 549$ [Praeneste], cf. Roman Latin pollux, polluces (Plautus Bach. 4, 8, 52)

(5) Feminine dative singular in $\underline{-a}<*$,ai

a. menerua DAT SG Minerva [deity] GG 59, cf. Roman Latin meneruai DAT SG $\mathrm{CIL} \mathrm{I}^{2}, 34$

b. filea DAT SG "daughter" CIL I², 60 [Praeneste] (Wachter 1987:212-213), cf. Roman Latin filiae DAT SG

fortuna primocenia DAT SG Fortuna Primogenia [deity] CIL I², 60 [Praeneste], cf.

Roman Latin fortunae primigeniae DAT SG

(6) $* \mathrm{iV}>\mathrm{eV}$

a. hileo "son" GG 97, cf. Roman Latin filius

filea "daughter" GG 67, cf. Roman Latin filia

b. fileai DAT SG "daughter" CIL I², 561 [Praeneste], filea DAT SG CIL I², 60, cf. Roman Latin filiae DAT SG

oueo masculine gentilicium CIL I ${ }^{2}, 234$ [Praeneste], cf. Roman Latin ouius ualereae feminine praenomen DAT SG, CIL XIV, 1724 [Ostia], Roman Latin ualeria

(7) loss of word-final $\underline{t}$

a. cupa 'lies' GG 121.I, cf. Roman Latin $\underline{\text { cubat }}$

b. dede 3SG PERF "gave" CIL 12, 47 [Tibur], cf. Roman Latin dedet CIL 12, 31 dedit $\mathrm{CIL} \mathrm{I}^{2}, 32$, coraueron 3PL PERF "administered" CIL I², 59 [Praeneste], cf. Roman Latin curauerunt 3PL PERF

[d]edero 3PL PERF "gave" CIL I², 61 [Praeneste], cf. Roman Latin dederunt 3PL PERF

(8) Loss of word-final $\underline{-s}$ after long vowels

a. cra "tomorrow" GG 5, cf. Roman Latin $\underline{\operatorname{cras}}$

b. matrona pisaurese NOM PL "ladies from Pisaurum" CIL I², 378 [Pisaurum], cf. matronae pisaurenses NOM PL (see footnote 12) 
sueq ABL PL "their own" CIL I², 62 [Praeneste], cf. Roman Latin suis-que

(9) $f>\underline{h}$ in word-initial position (with hypercorrection of etymological $\underline{h}$ to $f$ (Wallace $\&$ Joseph 1991))

a. hileo "son" GG 97, cf. Roman Latin filius

hirmio masculine gentilicium GG 61, cf. Roman Latin firmus

haba "bean" attributed by Terentius Scaurus to Falisci (GLK VII, 13), cf. Roman

Latin $f a b a$

(foied "today" GG 5, cf. Roman Latin hodie)

(fe "here" GG 144, cf. Roman Latin hic)

b. horda "pregnant cow" [Varro R.R. 2,5,6], cf. Roman Latin forda (faedus "goat" Varro L.L. 5, 97, cf. Roman Latin haedus)

(10) C-stem GEN in -os (>-us):

a. lartos GEN SG masculine praenomen GG 4a

loifirtato GEN SG "freedom" GG 25, cf. Roman Latin libertatis GEN SG

apolonos GEN SG Apollo [deity] GG 31, cf. Roman Latin apollinis GEN SG

b. salutus GEN SG Health [deity] CILI ${ }^{2}, 62$ [Praeneste], cf. Roman Latin salutis GEN SG

nationu GEN SG "birth" CIL I ${ }^{2}, 60$ [Praeneste]

diouos GEN SG Jove [deity] CIL I², 360 [Norba], cf. Roman Latin iouis GEN SG

(11) $\underline{o}$-stem GEN in $\underline{-o s i o}:^{14}$

a. euotenosio GEN SG masculine name GG $2 b$

kaisiosio GEN SG masculine praenomen GG 4b, cf. Roman Latin caesi GEN SG masculine praenomen

aimiosio GEN SG masculine praenomen GG 56, cf. Roman Latin aemi GEN SG masculine praenomen

b. popliosio ualesiosio GEN SG masculine praenomen and gentilicium CIL I ${ }^{2}$ (4) 2832a [Satricum]), cf. Roman Latin publi GEN SG masculine praenomen and valeri GEN SG masculine gentilicium CIL $\mathrm{I}^{2}, 503$

(12) $* \mathrm{erC}>\operatorname{irC}$ :

a. loifirtato GEN SG "freedom" GG 25, cf. Roman Latin libertatis GEN SG [I]oifirta "freedwoman" GG 73, cf. Roman Latin liberta

b. $\underline{\text { mircurios }}$ Mercury [deity] CIL I², 564 [Praeneste], cf. Roman Latin $\underline{\text { mercurius }}$

${ }^{14}$ For discussion of Faliscan genitives in -sio see G. Giacomelli (1978:518). It is possible that cauiosi[o] GEN SG masculine praenomen (?) GG 117, cf. Roman Latin gaui GEN SG masculine praenomen, is to be added to this list. However, one could also divide this sequence into cauio si[---] and interpret cauio as NOM SG (so VE 314). 
commircium "trade" attributed to 'antiqui' by Velius Longus (GLK VII, 77), cf. Roman Latin commercium

(13) $f$ (vs. Latin $\underline{b / d}$ ) in medial position:

a. efiles NOM PL "aediles [magistrates of public works]" GG 15, cf. Roman Latin aediles

carefo 1SG FUT "will be without" GG 5, cf. Roman Latin carebo

pafo/pipafo 1 SG FUT "will drink" GG 5

b. rufus "reddish", cf. Roman Latin $\underline{\text { ruber }}$ "red"

scrofa "breeding-sow"

Despite this seemingly impressive array of similarities there are certain facts that lead us to reject the conclusion that they point to dialectal Latin status for Faliscan, thereby calling into question the position in (3) above.

First of all, many of the changes found in (4) through (13) are changes that can be shown to have occurred relatively late in the history of Faliscan, quite apart from the fact that they are also late within Latin. ${ }^{15}$ For example, the features listed in (4), (5), (6), (7), (8), and (9) are not found in the earliest Faliscan inscriptions. Monophthongization of diphthongs in Faliscan does not begin to appear until the final phase of the Medio-Faliscan period. Forms with diphthongs appear alongside forms showing monopthongization even into the Neo-Faliscan period. Inscriptions from the 5th century preserve original diphthongs intact (e.g. kaisiosio GEN SG masculine praenomen GG 4b). ${ }^{16}$ With the single exception of Neo-Faliscan menerua, cited above in (5)a, the dative singular ending of $\underline{a}$-stem nominal forms is -ai in Faliscan, regardless of the period (e.g., karai DAT SG "beloved" GG 1 [c. 650 B.C.]; iunai DAT SG feminine praenomen GG 13.1[MF]). Similarly, in the earliest Faliscan inscriptions, original $*_{\mathrm{i}}$ is preserved in hiatus (e.g. prauios masculine praenomen GG 1 [c. 650 B.C], rufia VOC SG feminine gentilicium GG 3 [6th B.C.], kalketia VOC SG feminine gentilicium GG 3 [c. 6th B.C.]), word-final consonants are not weakened (cf. porded 3SG PERF "offered" GG 1 [c. 650 B.C.], f[if]iqod 3PL PERF "fashioned" GG 1 [c. 650 B.C.], titias GEN SG feminine praenomen GG 2 [6th B.C.], fifiked 3SG PERF "fashioned" GG 11 [c. 500 B.C.]), and the distinction between $f$ versus $\underline{h}$, reflecting developments from Proto-Indo-European $* \mathrm{bh} / \mathrm{dh}$ versus *égh, is maintained word-initially (cf. far ACC SG "spelt" GG 1 [c. 650 B.C.] < *bhars- "barley"; f[if]iqod 3PL PERF "fashioned" GG 1 [c. 650 B.C.] < *dhiégh- "to form" (full grade *dheiégh-); huti[c]ilom ACC SG "vasette" GG 1 [c. 650 B.C.] <*éghu- "to pour" (full grade *égheu-)). ${ }^{17}$

Thus, the changes cited in (4) - (9) are not attested in Faliscan much earlier than c. 300 B.C., a date which is, conservatively speaking, more than three hundred years after the first Faliscan inscriptions, and approaches the Neo-Faliscan period of post-241 B.C. As a result, these changes are much too late to be of any value whatsoever in a discussion of the

15 The few Latin inscriptions that date to the 7th and 6th centuries (see Wachter 1987) indicate that changes like monophthongization and the loss of final consonants $(-s,-d,-m)$ are to be dated no earlier than the fifth century.

16If the long diphthongs merged with the short ones in Faliscan, then karai DAT SG "beloved" GG 1 [c. 650 B.C.] and sociai VOC PL "friends" GG 3 [c. 6th B.C.] could be included as examples of the preservation of short diphthongs.

${ }^{17}$ Note that there is no direct evidence for the treatment of Proto-Indo-European $* \mathrm{gWh}$ in Faliscan. 
relative position of Faliscan and Latin, because Latin and Faliscan had to have diverged--or not diverged if one holds to that view--long before 300 B.C.

Next, we note that feature (10), namely the C-stem genitive in $\underline{-o s}(\underline{-u s})$ is also irrelevant since the variable realization of the vocalism of this ending across the IndoEuropean branches demands that several ablaut grades be reconstructed for the parent language category. In particular, C-stem singular genitives show both $*_{\text {-os }}$ and $*_{\text {-es }}^{18}$ (cf. Greek кuvéos GEN SG "dog" versus Old Lithuanian çsunes GEN SG "dog" from *ékunos/ékunes, respectively), presumably varying under specifiable conditions whose exact nature is not presently recoverable. What such proto-language variation means for the appearance of reflexes of $*_{-}$os in Faliscan and regional Latin dialects is that it need not constitute a true innovation; rather it is best interpreted, under the circumstances, as a shared retention, a selection from one of several allomorphs available in the proto-language. As such, it would be of no value for determining subgrouping.

The genitive of the $\underline{O}$-stem nouns, feature (11), is notorious for the variety it shows in the different branches of Indo-European, with reflexes of *-syo in Greek and Indo-

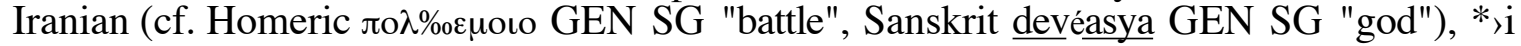
in Celtic and Latin, $19 *$-os in Hittite, etc. This variety is open to several interpretations, ${ }^{20}$ but whatever resolution may be given to this question, the Faliscan and dialectal Latin forms turn out to be irrelevant for the issue of subgrouping. In particular, if one reconstructs * syo for Proto-Indo-European, based on its occurrence in several branches that show no other special affinities amongst themselves, then the Faliscan and dialectal Latin forms would be shared retentions and thus not probative. If, however, ${ }^{*}$-syo is taken as a later development (say from an early PIE genitive in *-os, based on the Hittite evidence), then the appearance of *-syo in Greek, Indo-Iranian, etc. again makes its occurrence in Faliscan and dialectal Latin inconclusive for subgrouping, for it then would have to be an innovation that any Indo-European language in principle could have participated in and which would have to have occurred so early as to constitute a feature available in Proto-Italic.

Further, several features, including (4) monophthongization, (5) $a$-stem dative singular in $-\underline{a}$, (12) raising of *e before $r C$ clusters, and (13) $f$ in medial position from PIE labial and dental aspirates, are found also in languages that belong to the Oscan-Umbrian branch of Italic. ${ }^{21}$ Consequently, these features do not even define Latino-Faliscan, let

${ }^{18}$ The variant $*$-s must also be reconstructed, based on the genitives of $i$ - and $u$-stems (which pattern in general with the consonant-stems), e.g. Sanskrit agne-s "of fire" and relic forms such as Hittite nekuz ([nek $\left.\mathrm{W}_{\mathrm{t}-\mathrm{s}]}\right)$ "of evening" in the phrase nekuz mehur "evening (time)".

${ }^{19}$ Latin may also preserve the suffix *-osyo in pronominal forms, e.g. eius $<*$ esyo-s and cuius $<*$ kosyo-s. If these pronominal forms are so analyzed, then we have an additional reason to reject feature (11) as one shared by Faliscan and dialectal Latin to the exclusion of Roman Latin. Moreover, Faliscan inscriptions from end of MF period show a genitive in -i e.g. GG 73 I louci teti (= Luci Tetti). It is unclear, however, whether the appearance of this feature in Faliscan is due to Latin interference or whether its origins are to be linked with that of the Latin thematic GEN SG.

${ }^{20}$ See, for example, Szemerényi $(1989: 194-95,198)$ for discussion of and short bibliography on the genitive singular of the thematic declension.

${ }^{21}$ Another feature, namely (9), the change of $f$ to $h$ in word-initial position with cases of hypercorrection of $h$ to $f$, is found also in northern Etruscan dialects, e.g. Etruscan fuluna masculine gentilicium TLE 401 [Volaterrae III-I B.C.] vs. hulunias feminine gentilicium CIE 1900 [Clusium III-I B.C.], cf. vhulvena masculine gentilicium CIE 4952 [Orvieto VI 
alone regional varieties of Latin. Examples of these features in Oscan-Umbrian languages are given in (14) and following.

(14) Monophthongization *ai $>\underline{e}^{22} ; * \mathrm{ei}>\underline{e} ; *_{\mathrm{oi}}>\underline{o} ; *$ au $>\underline{o}$; *ou $>\underline{o}$ (cf. (4) above)

a. Umbrian pre "before" VIa $22<*$ prai

Volscian esaristrom ACC SG "expiatory sacrifice (?)" VE $222<*$ ais- (see below)

Marsian esos NOM PL "gods" VE 225, cf. Marrucinian aisos NOM PL "gods" VE 218

b. Umbrian iuve DAT SG Jove [deity] Ia 3, cf. Oscan diúveí DAT SG VE 147

Volscian se(pis) CONJ "if" VE $222<*$ sei, cf. Roman Latin $\underline{s i}$

c. Umbrian kuraia/k>or>ay>a/ 3SG PRES SUBJ "look after" < *kois>a-, cf. Paelignian written in coisatens 3PL PERF "administer" VE 214 (no Umbrian examples Latin alphabet)

d. Umbrian toru ACC PL "bull-calves" VIb 43, cf. Roman Latin taurus

e. Umbrian tota ACC SG "community" VIa $29<*$ tout am

Volscian toticu ABL SG "of the community" VE $222<*$ toutik〉od

(15) $\underline{a}$-stem DAT SG in $-\underline{a}<*$, ai (cf. (5) above)

Paelignian minerua DAT SG Minerva [deity] VE 203

Paelignian anaceta ceria DAT SG Anagtia Cerealis [deity] VE 204

(16) $* \mathrm{erC}>\operatorname{irC}$ (cf. (12) above)

Oscan amirikum ACC SG "advantage, profit" VE 3 (*erC $>$ irC before epenthesis), cf. Roman Latin merx, mercis "commodity"

Oscan amiricatud ABL SG "a bidding" VE 2 (*erC > irC before epenthesis)

Oscan mirikui DAT SG Mercury [deity] VE 136 (*erC > irC before epenthesis), cf. Faliscan mercui DAT SG Mercury [deity] GG 15.I

(17) $f$ in medial position (cf. (13) above)

Oscan mefiaí LOC SG "middle" VE $1<*$ medhyo-, cf. Roman Latin medius

South Picene mefiín LOC SG "middle" MA $1<*$ medhyo-, cf. Roman Latin medius

Umbrian alfu ACC PL "white" Ib $29<* a$ albho-, cf. Latin albus

Paelignian loufir "free" VE 209, cf. Latin liber

B.C.]; with hypercorrection: ferclite (CIE 1487, Clusium III-I B.C.) for herclite (CIE

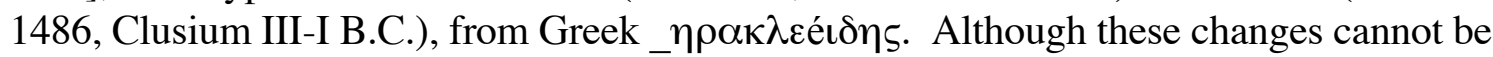
shown to be connected to the changes found in Faliscan or those found in dialectal Latin, the fact that they are attested in a language which is completely unrelated to Latin (and any other Indo-European language for that matter) suggests that this feature is not peculiar enough to be probative with respect to subgrouping.

${ }^{22}$ We note here that Etruscan also shows evidence of monophthongization of ai, though it appears to be tied to certain phonetic environments, e.g. before $\mathbf{v}$, e.g., masculine praenomen cnaive TLE 14 [Capua] > cneve TLE 300 [Volcii]. 
Finally, we note that the assumption (in many cases implicit) that the features listed in (4) through (13) are found only in inscriptions from outside the city Rome is also mistaken. There are inscriptions from Rome that attest some of the same features that have been used to group Faliscan with regional varieties of Latin. Thus these features are 'panLatin', at least in a geographical sense, and of no value in assessing the position of Faliscan with regard to Latin spoken in the city Rome. We give this evidence in (18) through (22).

(18) Monophthongization *ei $>\underline{e}$; *ou $>o$ (cf. (4) above)

a. Roman Latin hercole DAT SG Hercules [deity] CIL I², 30 Roman Latin honore DAT SG Esteem [deity] CIL I², 31

b. Roman Latin poloc/ Pollux [deity] CIL I², 2352

(19) $\underline{a}$-stem DAT SG in $-\underline{a}<*$,ai (cf. (5) above)

Roman Latin flaca DAT SG feminine praenomen CIL I², 477

Roman Latin [mi]nerua DAT SG Minerva [deity] CIL I², 460

(20) Loss of word-final - $\underline{t}$ (cf. (7) above)

Roman Latin dedron 3PL PERF "gave" CIL I ${ }^{2}, 30$

Roman Latin cepi 3SG PERF "seized" D321a (Wachter 1987:299)

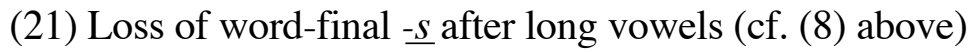

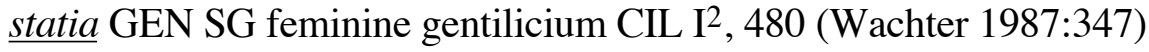

(22) C-stem GEN in $-\underline{o s}(>-\underline{u s})$ (cf. (10) above)

Roman Latin nominus GEN SG "name" CIL I², 581 [Senatus Consultum de

Bacchanalibus]

Roman Latin regus GEN SG "king" CIL I², 730

It should be clear by this point that the evidence brought forth for determining the position of Faliscan with respect to Latin, intriguing though it may be, is without value for dialectal subgrouping. Moreover, the uses to which this evidence has been put are severely flawed from a methodological standpoint. Not only the chronology of these features in Faliscan (and in Latin) but also the appearance of many of these same features throughout the central portion of ancient Italy and within the city of Rome make them unusable for distinguishing among dialects of Latin ${ }^{23}$ and thus similarly without utility for determining

${ }^{23}$ Other features often cited as evidence of 'dialectal' Latin, especially the occurrence of $a f$ and $\underline{a r}$ respectively for Roman Latin preverb/prepositions $\underline{a b}$ and $\underline{a d}$, also turn out to be useless for Latin dialectology, as Brent Vine has reminded us, inasmuch as they are attested within Rome (e.g. arf. in CIL I ${ }^{2}, 581$ and af.vobeis in CIL I ${ }^{2}, 586$; moreover, these features are irrelevant for the issue at hand here since they are not found in Faliscan. The fact that some of these 'dialectal' features are found in Rome may point to different sociolects existing within the city. We hardly find this surprising, when it is recalled that Rome was 
early dialect affinities within Italic. The most that this evidence can do is point to areal developments in (central) Italy 24 in the period during the expansion of the city Rome. This is an important issue in and of itself but it does not permit one to conclude that Faliscan is a regional variety of Latin.

\section{Towards a Solution}

We turn now to the evidence which in our view provides the best solution to the problem of the relationship of Latin and Faliscan. As suggested at the outset, any such solution necessarily involves the clarification of the place of Latin and Faliscan within Italic. First, therefore, we establish that Latin and Faliscan form a subgroup within Italic, thereby arguing against the position represented above in (2) in which Latin, Faliscan, and OscanUmbrian are parallel siblings in the Italic family tree. Then we move to a consideration of where Latin and Faliscan fit in with respect to one another within that subgroup.

\subsection{Evidence for Grouping Faliscan with Latin}

Based on the methodological prerequisites adopted in section 2, in order to demonstrate that Latin and Faliscan form a subgroup within Italic, it is essential to isolate some early shared innovations that serve to set the two together off from the OscanUmbrian languages. There are two such features which seem significant in this context.

The first of these features is the formation of a future tense by means of a labial suffix, -f- in Faliscan and - $\underline{b}$ - in Latin, e.g. Latin carebit 3SG FUT "will lack", or amabit 3SG FUT "will love", and Faliscan pipafo 1SG FUT "I will drink" GG 5 and carefo $1 \mathrm{SG}$ FUT "I will lack" GG 5. By contrast, the Oscan-Umbrian languages have an s-future, e.g. Oscan didest 3SG FUT "will give" VE 2, Umbrian ferest 3SG FUT "will bear" IIa 26, and show no trace whatsoever of a labial future suffix. ${ }^{25}$

The source of this labial future has been greatly debated in the literature (see Leumann 1977:579-580 and Jasanoff 1978:121ff.). For the discussion here, however, the details of the origin of this future formation are not relevant; what matters is that the labial suffix in each language can be derived from a common source, i.e. there is nothing problematic in the phonological correspondence of medial $-\underline{b}$ - in Latin to a Faliscan -f-. Even though there are no direct parallels to this development, Faliscan shows -f- medially corresponding to Latin voiced stops, from other of the Proto-Indo-European voiced aspirates, as in efiles GG 15.I and loifirtato GG 25 corresponding to Latin aediles and libertatis, respectively; thus the correspondence in the future suffix is an expected one. Furthermore, even though the Latin and Faliscan futures for the verb "drink" show different formations, these differences can be explained by the fact that the present stems belong to

the commercial and political center that attracted people from all over Latium. Thus, these 'dialect' features within Rome may well represent the transformation of original geographic isoglosses into socially-determined ones.

${ }^{24}$ This is a topic that is in need of more investigation. See Campanile (1976) and Meiser (1987) for some discussion.

25 It has been suggested by R. Giacomelli (1978:13-19) that the Latin $b$-future and the Oscan-Umbrian $\boldsymbol{s}$-future both derive from a preform with $*_{-s w-,}$ a suggestion which, if correct, would vitiate the relevance of the $-b$-/-f-future as an isogloss uniting Faliscan and Latin. However, we find this view is unconvincing for phonological reasons. Medial *-swclusters develop to -rr- (via *-rw-), not to -s-, in (Oscan-)Umbrian (Meiser 1986:183-185, 192-194). As a result, it is incumbent upon those who argue for such a preform to spell out in detail the developments required to obtain s-futures in Oscan-Umbrian from a suffix with medial *-sw-. We also follow Thurneysen (1970:\$637) and Watkins (1966:41) in dismissing any connection between the Latin $b$-future and the $f$-future found in Celtic (e.g. Old Irish leicfid 3SG "will leave"). 
different conjugational classes (Faliscan has an f-future built from an / / a/-stem present, ${ }^{26}$ while Latin shows the future signs characteristic of thematic presents, $-\underline{a}-/ \underline{e}-(=/ / \mathrm{a}$, , e/ $)$, e.g. 1SG FUT bibam, 3SG FUT bibet). Moreover, Faliscan carefo is directly equatable with Latin carebo. Thus at most, Faliscan and Latin show a different lexical spread of the labial future, but that in itself does not diminish the value of the presence of ostensibly the same marker for future in the two languages with in all probability the same distributional pattern ( $f$-future to stems in //a/ and / e $/$ ). It may be concluded then that the labial future offers an instance of a morphological element that is found in both Latin and Faliscan but not in Oscan-Umbrian, and therefore can be taken to represent a Latino-Faliscan shared innovation.

It is of course the case that Latin presents other 'futuroid' formations (see Schmidt 1986:33 for this terminology) besides the labial future, not just the $\underline{a} / \underline{e}$-future evident in bibam/bibet but also traces of an $\underline{s}$-formative in such Old Latin forms as faxo 1SG (e.g. Plautus Bacch. 848) built from the root found in facit "makes". While faxo might at first seem to indicate an affinity between Latin and Oscan-Umbrian with regard to the future, it should be noted that the $\underline{s}$-marker for the future is clearly an inherited formative from ProtoIndo-European (compare Greek $\delta \varepsilon e ́ \imath \xi \varepsilon \iota 3 S G$ FUT "will show" from *deiék-s-, Old Irish seiss 3SG FUT "will sit" from *sed-s-ti, etc.). Thus, Proto-Italic must have inherited the capability for forming a future with the suffix $-\underline{s}-$, a formation that was then passed along as the primary future in Oscan-Umbrian and as a (perfective?) future for at least certain verbs still in Old Latin. 27 The occurrence of these other futuroid types in Latin, however, merely emphasizes the innovative nature of the labial future, and, given its total absence from Oscan-Umbrian, 28 it must have become available at some point between Proto-Italic and Proto-Latino-Faliscan. Consequently, it seems justifiable to take the labial future in Latin and Faliscan at face value as a significant shared innovation between the two languages, permitting their subgrouping within Italic.

A second such innovation that is restricted just to Latin and Faliscan is the addition of a particle $-d$ to the accusative singular of personal pronouns, e.g. first person $\underline{m e d}$, attested in Archaic Faliscan (med GG1) and in Old Latin (e.g. CIL I ${ }^{2}, 4$, and in Plautus). By contrast, the Oscan-Umbrian languages have accusatives formed by addition of a particle *-om, e.g. Umbrian tiom "you" VIa 43. These forms in $\boldsymbol{- d}$ have no obvious source. While a *-d is found in Indo-European pronominal forms in both ablative singulars (e.g. Sanskrit mád ABL SG "from me", tvád ABL SG "from you") and neuter nominative/accusative singular (e.g. Latin aliud "other", Sanskrit anyád "other"), neither constitutes an acceptable starting point for personal accusatives in $-\underline{d}$ since they represent such vastly different categories; there is no basis, semantic or otherwise, for a shift from ablative to accusative or from neuter to animate. Consequently, these personal accusatives in $-d$ in Latin and in Faliscan constitute a shared peculiarity that points directly to a common innovation; two

26 The stem of Faliscan pipafo, pipa-, must reflect a deverbative formation in $-\boldsymbol{a}<*$ bib $>$ asimilar to that attested in Umbrian andersafust 3SG FUT PERF "encircle" VIIb 3

$<*$ am(b)-did a-.

27 The basic facts on these $s$-forms in Latin can be found Leumann (1977:621-624). See Jasanoff (1975) and Schmidt (1986) for an investigation of futures in $-s$ in Indo-European. ${ }^{28} \mathrm{We}$ are aware that Oscan shows an imperfect fufans 3PL IMPF "were" VE 1 that has a labial element which in some accounts (see Leumann 1977:579 and Jasanoff 1978:121ff.) is related to the labial future, being originally a preterite of *bhew $(\mathrm{H})-$ "be $(\mathrm{come}) "$. This form would suggest that Oscan-Umbrian had the material that could have led to the labial future; the absence of the labial future would then become all the more significant as a Latino-Faliscan innovation. 
languages would be unlikely to have innovated these forms independently, whatever they represent etymologically. ${ }^{29}$

There may well be other innovations that unite Latin and Faliscan and set them together off from the Oscan-Umbrian branch of Italic, but these two at the very least are sufficient to point to this subgrouping within Italic. 30 Thus, the position represented in (2) above cannot be maintained, and the question of the relation of Faliscan to Latin becomes one of determining whether there are grounds for separating Faliscan from all forms of Latin and for uniting all forms of Latin excepting Faliscan. We examine the evidence relevant to this issue in the next section.

\subsection{Innovations separating Faliscan and Latin}

Having ruled out the possibility that Faliscan belongs to a separate branch of Italic distinct from Latin and Oscan-Umbrian, we turn now to a consideration of the remaining positions. Crucial for deciding the position of Faliscan vis-à-vis Latin are any chronologically early innovations found in one language that are not found in the other. In this section we consider two such innovations that separate Latin from Faliscan, both of which happen to involve the development of Proto-Italic *x, the result of a merger of the Proto-Indo-European voiced aspirated palatal and velar stops, ${ }^{*} \% \mathrm{gh}$ and ${ }^{*} \mathrm{gh} .{ }^{31}$

As the first example of such an innovation pointing to the divergence of Faliscan and Latin, we offer the development of Proto-Italic *x in intervocalic position.

${ }^{29}$ Thus, it is irrelevant if the personal accusative singular $-d$ was available as an option in Proto-Italic (along with the *-om found in Oscan-Umbrian) for extending the personal accusative singulars, for one has still to reckon with the selection by both Latin and Faliscan of this extension to the exclusion of the *-om element.

30 We realize, of course, that this conclusion holds only in a strict Stammbaum model, but since there are no innovations within Latin or within Faliscan that must have preceded these, there is no conflict with the Stammbaum assumptions. Moreover, given that there are in addition some other potentially significant innovations, it is hard to assume that all of these features occur in both languages through a wave-like spread. For example, within the lexical domain of time adverbials, Latin and Faliscan both show *krsas (Latin cras, Faliscan cra GG 5) for "tomorrow", a form which is without any plausible connections outside of Italic, and both show reflexes of *gho-dysed for "today" (Latin hodie, Faliscan foied GG 5 ), with the shared use of the deictic element *gho- (presumably the same as the Vedic emphatic particle $g h a$ ) as opposed to the *ki- deictic found in most other languages in this

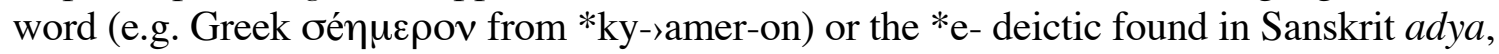
and possibly the shared peculiarity of a short $o$ in this deictic element, if Faliscan $\mathbf{o}$ represents here a short vowel, for a long $>0$ would be expected if an ablative in origin. Unfortunately, however, the words for "today" and "tomorrow" are not known for any Oscan-Umbrian language, so no certain assessment of the extent of the innovations in these expressions can be made.

31The precise path taken by these developments, in Faliscan and in Latin, depends on one's view of the prehistory of the development of PIE aspirates in Italic. If one follows the standard view (see Risch 1979), for example, then Latino-Faliscan inherited from ProtoItalic a voiceless velar spirant $* x$ in intervocalic position $\left(<*_{0} \mathrm{gh} / \mathrm{gh}\right)$. For Faliscan we must assume that *x came to be stopped (and possibly voiced as well); in Latin, on the other hand, *x was weakened to $h$ and subsequently lost. If, however, one adopts the view advocated by Rix (1957) and Meiser (1986), then Latino-Faliscan inherited a voiced velar spirant $* \gamma$. In Faliscan this sound developed regularly to either $/ \mathrm{g} /$ or $/ \mathrm{k} /$; in Latin $* \gamma$ is devoiced to $* \mathrm{x}$ and then subsequently weakened to $h$, etc. 
For Faliscan there are three forms that are relevant here: lecet 3SG PRES "lies" GG 85, either a thematic present or a stative in $*_{>}$e based on the root *legh-, f[if]iqod 3PL PERF "fashioned" GG 1, and fifiked 3SG PERF "fashioned" GG 11, both of which are reduplicated perfects built from the zero-grade *dhi\%gh- of *dhei\%gh-.

It is important first to note that the outcome of the Proto-Italic $* x(<\mathrm{PIE}$ aspirates $*_{\%} \mathrm{gh} / \mathrm{gh}$ ) is indicated in Faliscan by the graphemes $\mathbf{c}, \mathbf{k}$, and $\mathbf{q}$. It is impossible to say with certainty whether the sound or sounds represented by these graphemes here are voiced or voiceless, since the Faliscan writing system does not distinguish between $/ \mathrm{k} /$ and $/ \mathrm{g} /$, the letters $\mathbf{c}, \mathbf{k}$, and $\mathbf{q}$ serving to represent both sounds. Nevertheless, from the values of the letters in words where the phonology is secure (e.g. eqo $1 \mathrm{SG}$ PRO "I" GG $1=$ /eg>o/, cf. Latin ego; cauio NOM SG masculine praenomen GG 63 =/g)awio/, cf. Latin gauius; ceres NOM SG Ceres [deity] GG 1 =/kerses/, cf. Latin ceres; hec "here" GG 86.V = /h>ek/, cf. Latin $\underline{\text { hic }}$ ), there can be little doubt that these graphemes represent stop consonants in the three verbs at issue.

Of these three forms, the most significant and clearest is lecet. As noted above, it

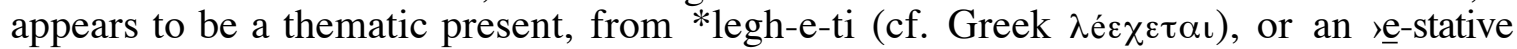
formation, from *legh->e-ti (cf. OCS stem leczza- "lies", from *leczCe-). As such, it would directly attest to a development of Proto-Italic intervocalic *x $(<$ PIE $* g h)$ to a velar stop in Faliscan.

One possible objection to this conclusion can be raised, which, however, can be dispensed with. For this root *legh-, Old Church Slavonic has, besides the stative formation just mentioned, a nasal-infix thematic formation as well, e.g. $l \leq e g \leq 0$ 1SG PRES "I lie down". This OCS form raises the possibility of explaining the occurrence of $\mathbf{c}$ in lecet as simply a nasal-less writing for a nasal-plus-stop cluster $/ \mathrm{ng} /$ (or even, in principle, /nk/), not unlike the suppression of the nasal in the 3PL endings written as od (perfect) and at (present) from *-ont and *-anti, respectively (cf. f[if]iqod 3PL PERF "fashioned" GG 1, and cupat 3PL PRES "lie" GG 97), ${ }^{32}$ which therefore would not show the intervocalic outcome of $*_{\mathrm{x}}\left(\mathrm{PIE} *_{\%} \mathrm{gh} / \mathrm{gh}\right)$ at all. However, there is no strong evidence for a ProtoIndo-European nasal-infix present with this root; the OCS form most likely represents the effects of an innovative Balto-Slavic extension of productivity for this stem-forming process (note, for instance, that *sed- "sit" has a nasal-infix present only in Balto-Slavic, cf. OCS $s \leq e d^{-} o$ 1SG PRES "I sit down", Old Prussian sindats NOM SG "sitting down"). 33 While Latin admittedly shows a similar extension of the nasal presents, e.g. in -cumbit "lies down", fundit "pours", etc., the absence of a present *lingit <*leng- in Latin means that there is no good reason to take the phonetic value of the verbal form written as lec- as anything other than [leg-] (or [lek-]).

The situation with f[if]iqod and fifiked is somewhat less straightforward, but the forms can nonetheless be taken to show the same development as lecet. The single $\mathbf{q} / \mathbf{k}$ in these verbs could conceivably represent a nasal-less writing for [nk] or [ng], and the occurrence of a nasal in the Latin perfect finxit makes such an assumption attractive, especially since there is support for a nasal-infix present for this root in Latin and elsewhere

32 That nasal-plus-stop clusters can be written in full is shown by the form arcentelom "made of silver", from *argent-elo-, which is in the same inscription (GG 1) as f[if]iqod.

33 Admittedly, Vedic sasand>i "throne" might show a nasal-present for *sed- outside of Balto-Slavic (see Mayrhofer 1953:83), but other roots make the same point that the Slavic nasal infix formations show the results of innovative expansion in the Proto-Balto-Slavic period, with subsequent reduction of productivity in Slavic that left behind only a few relic forms, a view that is implicit in the discussion in Stang 1966:338ff. We are indebted to Charles Gribble and Brent Vine for clarification on this point. 


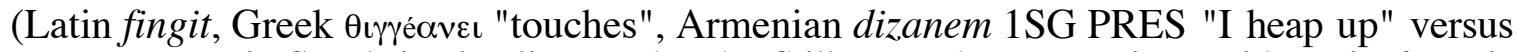
a root present in Sanskrit dégdhi "touches"). Still, even the comparison with Latin finxit is not compelling, for with this verb (and others as well, e.g. iungit "joins" with perfect iunxit), the spread of the nasal infix into the perfect system is an innovation, and is one that was only partially achieved at that, inasmuch as the perfect passive participle is the nasal-less fictus. Moreover, there are nasal-infix verbs in Latin that have the nasal restricted just to the present, that is with the inherited distribution of the allomorph containing the nasal, as with the present rumpit "bursts" versus the perfect rupit "burst". Both f[if]iqod and fifiked are perfects, so all things being equal, the expectation would be that they follow the inherited distribution of the nasal marker in not having a nasal; this conclusion is especially attractive since there is no independent evidence for the secondary extension of nasals into the perfect system in Faliscan. Thus the appearance of a nasal in the perfect of $*$ dhei\%ogh- seems best taken to be purely a Latin innovation and not a Latino-Faliscan or Italic one. Overall, then, there is no compelling evidence pointing to the interpretation of f[if]iqod and fifiked as containing a nasal phonetically which could have conditioned the occurrence of the velar stop; the burden of proof seems clearly to lie with anyone making such a claim and not with anyone advocating the otherwise straightforward interpretation of the $\mathbf{q}$ and $\mathbf{k}$ as simple velar stops.

Thus, taking these forms at face value, one reaches the conclusion that the regular development of Proto-Italic *x (PIE *\%gh/gh) in medial position in Faliscan is to a velar stop whose voicing cannot be determined, i.e. to either $[\mathrm{k}]$ or $[\mathrm{g}]$.

In Latin, by contrast, both $\underline{h}$ and $g$ are found as reflexes of Proto-Italic ${ }^{*} \mathrm{X}$ (PIE

${ }^{*} \% \mathrm{gh} / \mathrm{gh}$ ) in intervocalic position. ${ }^{34}$ However, the weight of the evidence argues in favor of $\underline{h}$ as the regular development in this environment, e.g. uehit "he transports" <*we\%gh-; mihi DAT SG "to me" < Proto-Italic *mexei, cf. Umbrian mehe DAT SG VIa 5.

Latin does have a few words containing medial $g$ from $*_{\%} \mathrm{gh} / \mathrm{gh}$, as in for example figulus "potter", figura "form", and effigies "imitation", but these do not violate the abovestated sound law; instead they are to be explained by means of context-sensitive phonological developments (e.g.figulus < *figlo- <*dhi\%ghlo-) or by means of analogy from stem-forms in which the velar stop was regular, for example after a nasal (note the nasal-infix present fingit from *dhi-n-\%ogh-).

Thus, we conclude that Latin, by which we mean all varieties of Latin (in the absence of evidence to the contrary), and Faliscan differ in their treatment of Proto-Italic ${ }^{*} \mathrm{x}$, from the PIE aspirates $*_{\%} \mathrm{gh} / \mathrm{gh}$, in intervocalic position. Moreover, the Faliscan evidence points to a change which is chronologically early within Faliscan. The verb f[if]iqod is attested on the earliest Faliscan inscription, GG 1, which dates roughly to the middle of the 7th century B.C. As a result, the development of Proto-Italic *x to [g] (or [k])--written as $\mathbf{c}, \mathbf{k}$, or $\mathbf{q}$ in the Faliscan alphabet--must be assigned to the prehistory of Faliscan and thus is best taken to constitute an early and significant innovation that Faliscan underwent as it developed from Proto-Latino-Faliscan, separating it from its sister language Latin.

As another example of an innovation distinguishing Latin and Faliscan, the development of Proto-Italic *x (whether from PIE *\%gh or *gh) in word-initial position can be cited. For Latin the evidence unequivocally indicates that $\underline{h}$ is the regular development in this environment, e.g. hiems "winter" < *\%oghiem-; haedus "goat" < *ghaido-; $\underline{\text { hic }}$ "here" <*ghei-ke. ${ }^{35}$ However, before the vowel $\underline{u}$, we find evidence for a

34This is the standard view. See Buck (1933:127); Leumann (1977:165); Meillet-Vendryes (1953:72); Palmer (1954:229); Sommer-Pfister (1977:141-42).

${ }^{35}$ The dialectal Latin substitution of $f$ for etymological $h$ (e.g. fedus "goat" P. F. 74, 9L, cf. haedus $<$ *ghaido-) is to be explained, in our view, by positing a hypercorrection of $h$ to $f$, 
context-sensitive change in which the outcome is $f$, rather than $\underline{h}$. Examples of this treatment are provided by the family of words derived from the PIE root $*_{\%}$ ghu- (full grade $*_{\%}$ gheu) 'pour': fundit "pours", futis "water vessel", etc. Admittedly, this root constitutes the only solid evidence in favor of such a change, but there is nothing in Latin to suggest any development to the contrary. ${ }^{36}$ As a result, we see no reason not to accept this change as valid for Latin (for references, see footnote 34).

In Faliscan, on the other hand, the evidence also points to $\mathbf{h}$ as the regular reflex of Proto-Italic *x in word-initial position, e.g. hec "here" GG $86 . \mathrm{V}=/ \mathrm{h}$ >ek/ <*xei-ke (from the PIE deictic element *gho-). But what is important here is that the available Faliscan evidence also indicates that the treatment of $*^{*} \mathrm{x}$ as $\mathbf{h}$ is found even before the vowel $\underline{\mathbf{u}}$. In Archaic Faliscan, the word huti[c]ilom "vasette" GG 1 is found, an apparent diminutive formation derived from a stem *huti- (= Latin futi-) $<* x u-($ from PIE*\%ghu-), showing an $\mathbf{h}$ in word-initial position before $\mathbf{u}$, where the outcome in Latin, as noted above, is $f$. Crucially, one cannot claim here that Faliscan $\mathbf{h}$ in huti[c]ilom is from earlier $* f$, since $\mathbf{f}$ from PIE *bh and *dh is regularly maintained in the earliest Faliscan inscriptions (see Wallace \& Joseph 1991). As a result, Faliscan and Latin can be said to have diverged from one another in their treatment of Proto-Italic *x (PIE *\%gh) in word-initial position before $\underline{u}$.

It is possible that there are still other innovations that serve to set Latin off from Faliscan and vice versa, but an exhaustive survey of the possiblities is not the aim of this section. ${ }^{37}$ Rather, our aim has been to show that chronologically early innovations do exist

induced by a dialectal sound change taking etymological $f$ to $h$ (e.g. horda "pregnant cow" Varro R.R. 2.5.6, cf. forda < *bher-) and possibly based on models provided by Latin dialects, like that found in the city Rome, that preserved an $f$ vs. $h$ distinction in word-initial position.

${ }^{36}$ Note that fundit, futis, etc. are unlikely to show an initial $f$ as the result of hypercorrection (see footnote 35 ) because these words occur with $f$ in all of Latinity, show no variant forms with initial $h$ (as opposed to the coexistence of such by-forms in most of the hypercorrection cases, e.g. fedus/haedus "goat"), and provoked no particular mention by any ancient commentators.

${ }^{37}$ Perhaps the best remaining example is the development of the inflectional endings of the so-called 'perfect' tense. If Latino-Faliscan inherited two sets of endings from Proto-Italic (see Watkins 1969), one reflecting an earlier thematic aorist and another reflecting the perfect, then it can be argued that Faliscan and Latin selected from this common patrimony and constructed distinct sets of inflectional endings for each language. For example, the Faliscan evidence indicates that the perfect 3SG and 3PL endings, -ed and -od respectively, go back to thematic aorist endings $<*$-et, *-ont. In Latin, however, the 3SG ending has two sources, a thematic aorist $<*$-et and a perfect $*$-ei(t). Latin has also preserved 3PL endings derived from the PIE perfect and aorist. 3PL -ere /sere/ reflects the PIE perfective ending with the addition of the deictic particle *-i. The ending -erunt/erunt/ is generally regarded as an old thematic aorist ending which has been appended to an *-is- element whose origin is unclear. - erunt/serunt/ is most likely a blending of the two endings cited above. Thus, both Latin and Faliscan have remodelled the endings of the 'perfect' tense by drawing on endings inherited from Proto-Italic. But the important point here, even if we cannot be precisely sure of steps involved in creation of these endings, is that each language has innovated away from the other in the formation of endings for the 'perfect'.

Similarly, the lexical substitution of iacet "lies" in Latin for what was undoubtedly the inherited root for "lie", namely *legh-, represented as a verb in Italic by Faliscan lecet and possibly South Picene veiat if from *legh-y>a- (Brent Vine, p.c.), provides another development that is possibly noteworthy in this context. Latin iacet is an innovative formation, presumably a stative, built on iacit "throws" (hence ultimately on PIE *yeH ${ }^{-}$), and is apparently restricted just to Latin. Its substituting for inherited *legh-, therefore, is 
in Faliscan and in Latin that set these two apart and point to the relationship described in (1) above, where Faliscan and Latin are considered to be immediate siblings in the Italic family tree.

\section{Conclusion}

The overall force of the evidence brought forth here points towards the conclusion that Faliscan is not a dialect of Latin. Not only are the features typically adduced in support of the view of Faliscan as dialectal Latin inadmissible once well-established principles for subgrouping of dialects are brought into play, but there are as well significant innovations that separate Faliscan and Latin off from each other. Some unite all Latin dialects but exclude Faliscan and others are found only in Faliscan to the exclusion of all of Latinity. These facts therefore confirm the traditional view that Latin and Faliscan are distinct languages, though closely related to one another as immediate siblings.

Authors' addresses:

Brian D. Joseph

The Ohio State University Department of Linguistics 204 Cunz Hall COLUMBUS, OH 42310 U.S.A.

\author{
Rex E. Wallace \\ The University of Massachusetts, Amherst \\ Department of Classics \\ 528 Herter Hall \\ AMHERST, MA 01003
}

\section{REFERENCES}

Adiego Lajara, I.-J. 1990. "Der Archaismus des Südpikenischen". Historische Sprachforschung 103.69-80.

Beeler, Madison. 1956. "Venetic and Italic". Hommages à Max Niedermann, 38-48. Bruxelles.

-------. 1966. "The Interrelationships within Italic". Ancient Indo-European Dialects ed. by Henrik Birnbaum \& Jan Puhvel, 51-58. Berkeley \& Los Angeles: Univ. of California Press.

Buck, Carl Darling. 1933. Comparative Grammar of Greek and Latin. Chicago: Univ. of Chicago Press.

Campanile, Enrico. 1961. "Elementi dialetti nella fonetica e nella morfologia del Latino". Studi e saggi linguistici 1.1-21.

-------. 1968. "Studi sulla posizione dialettale del latino". Studi e saggi linguistici 8.16130.

------. 1976. "La latinizzazione dell'Osco". Scritti in onore di Giuliano Bonfante ed. by Vittore Pisani, Giacomo Devoto, Antonino Pagliaro, Vol. I, 109-120. Brescia: Paideia.

Conway, R[obert] S[eymour]. 1897. The Italic Dialects. Vol. I. Cambridge: Cambridge Univ. Press. (Repr., Hildesheim: Georg Olms, 1967.)

Corpus Inscriptionum Etruscarum. Vol. I ed. by Carol Pauli; Vol. II: 1.1 ed. by Carol Pauli, Olav Danielsson, Gustav Herbig \& Bartholomae Nogara. 1893-1907. Leipzig: J. A. Barth.

Corpus Inscriptionum Latinarum. Vol. I2: 2.1-4: Inscriptiones Latinae Antiquissimae ad C. Caesaris mortem ed. by Ernest Lommatzsch, Atilius Degrassi, Johann Krummrey; Vol. XIV: Inscriptiones Latii Veteris Latinae ed. by Hermann Dessau. 1887-1986. Berlin: Georg Reimer \& Walter de Gruyter.

an innovation in which all of Latinity, but--significantly--not Faliscan, participated. Latin lectus "bed" shows that the root *legh- survived in the language in derived forms, so that the replacement for "lie" affected only the primary verb. 
Cowgill, Warren \& Manfred Mayrhofer. 1986. Indogermanische Grammatik. Band I. 1. Halbband: Einleitung, by Warren Cowgill; 2. Halbband: Lautlehre [Segmentale Phonologie des Indogermanischen], by Manfred Mayerhofer. Heidelberg: Carl Winter.

Degrassi, Atilius. 1957. Inscriptiones Latinae Liberae Rei Publicae. Firenze: La nuova italia.

Diver, William. 1953. The Relation of Latin to Oscan-Umbrian. Unpublished dissertation, Columbia Univ., New York.

Ernout, Alfred. 1909. Les éléments dialectaux du vocabulaire latin. Paris: Honoré Champion.

Eska, Joseph F. 1987. "The Language of the Latin Inscriptions of Pompeii and the Question of an Oscan Substratum". Glotta 65.146-161.

Giacomelli, Gabriella. 1963. La lingua Falisca. Firenze: Leo S. Olschki.

-------. 1978. "Falisco". Popoli e civilta dell'Italia antica. Vol. VI: Lingue e dialetti ed. by Aldo Prosdocimi, 507-539. Rome: Giorgio Bretschneider.

Giacomelli, Roberto. 1978. Problemi di storia linguistica del latino dialettale. Vol. I: Ricerche falische. Firenze: La nuova italia.

-------. 1979. "Written and Spoken Language in Latin-Faliscan and Greek-Messapic". Journal of Indo-European Studies 7.149-175.

Hoenigswald, Henry. 1960. Linguistic Change and Linguistic Reconstruction. Chicago: Univ. of Chicago Press.

Jasanoff, Jay. 1975. "The Baltic Future". Harvard Studies in Indo-European ed. by Calvert Watkins, Vol. II, 90-100. Cambridge, Mass.: Department of Linguistics, Harvard Univ.

-------. 1978. Stative and Middle in Indo-European. Innsbruck: Innsbrucker Beiträge zur Sprachwissenschaft.

Keil, Heinrich, ed. 1880. Grammatici Latini. Vol. VII: Scriptores de orthographia. Leipzig: B. A. Teubner. (Repr., Hildesheim: Georg Olms, 1961.)

Leumann, Manu, J[ohann] B[aptist] Hofmann, \& Anton Szantyr. 1977/1972. Lateinische Grammatik. Vol. I: Lateinische Laut- und Formenlehre, by Manu Leumann; Vol. II: Lateinische Syntax und Stilistik, by J. B. Hofmann \& Anton Szantyr. München: H. C. Beck.

Maniet, Albert. 1972. "La linguistique italique". Aufstieg und Niedergang der römischen Welt. Vol. I, 2: Von den Anfängen Roms bis zum Ausgang der Republik ed. by Hildegard Temporini, 522-592. Berlin \& New York: Walter de Gruyter.

Marinetti, Anna. 1985. Le iscrizioni sudpicene. Vol. I: Testi (= Lingue e iscrizioni dell'Italia antica, 5.) Firenze: Leo S. Olschki.

Mayrhofer, Manfred. 1953. Kurzegefasstes etymologisches Wörterbuch des Altindischen. A Concise Etymological Sanskrit Dictionary. Vol. I. Heidelberg: Carl Winter.

Meillet, Antoine. 1933. Esquisse d' une histoire de la langue latine. Paris: Librairie Hachette.

Meillet, Antoine \& Joseph Vendryes. 1953. Traité de Grammaire comparée des langues classiques. 2nd ed. Paris: Honoré Champion.

Meiser, Gerhard. 1986. Lautgeschichte der umbrischen Sprache. Innsbruck: Innsbrucker Beiträge zur Sprachwissenschaft.

-------. 1987. "Pälignisch, Latein und Südpikenisch". Glotta 65.104-125.

Palmer, Leonard. 1954. The Latin Language. London: Faber \& Faber.

Pallottino, Massimo. 1968. Testimonia linguae etruscae. 2nd ed. Firenze: La nuova italia.

Pisani, Vittore. 1962. "Il falisco nella formazione del più antico latino 'volgare'". Ricerche linguistiche 5.55-64.

Polomé, Edgar. 1966. "The Position of Illyrian and Venetic". Ancient Indo-European Dialects ed. by Henrik Birnbaum \& Jan Puhvel, 59-76. Berkeley and Los Angeles: Univ. of California Press. 
Poultney, James W. The Bronze Tables of Iguvium. Baltimore: The American Philological Association.

Pulgram, Ernst. 1978. Italic, Latin, Italian: 600 B.C. to A.D. 1260. Heidelberg: Carl Winter.

Renzetti Marra, Stefania. 1974. "Falisco". Studi Etruschi 42.350-357.

Risch, Ernst. 1979. "Die idg. Wurzel *reudh- im Lateinischen". Festschrift for Oswald Szemerényi on the Occasion of his 65th Birthday ed. by Bela Brogyanyi, 705-724. Amsterdam: John Benjamins.

Rix, Helmut. 1957. "Sabini, Sabelli, Samnium". Beiträge zur Namenforschung 8.127143.

Schmid, Wolfgang. 1965. "Zur Goldfibel von Praeneste". Indogermanische Forschungen 70.200-208.

Schmidt, Gernot. 1986. "Zum indogermanischen s-Futur". O-o-pe-ro-si: Festschrift für Ernst Risch zum 75.Geburtstag ed. by Andreas Etter, 33-59. Berlin \& New York: W. de Gruyter.

Sittl, Karl. 1882. Die lokalen Verschiedenheiten der lateinischen Sprache. Erlangen.

Sommer, Ferdinand \& Raimund Pfister. 1977. Handbuch der lateinischen Laut- und Formenlehre. 4th rev. ed., Band 1: Einleitung und Lautlehre by Raimund Pfister. Heidelberg: Carl Winter.

Stang, Christian. 1966. Vergleichende Grammatik der baltischen Sprachen. OsloBergen-Tromsö: Universitetsforlaget.

Szemerényi, Oswald. 1989. Einführung in die vergleichende Sprachwissenschaft. 3rd rev. ed. Darmstadt: Wissenschaftliche Buchgesellschaft.

Thurneysen, Rudolf. 1970. A Grammar of Old Irish (Revised and Enlarged Edition, translated form the German by D. A. Binchy and O. Bergin). Dublin: The Dublin Institute for Advanced Studies.

Vetter, Emil. 1953. Handbuch der italischen Dialekte. Heidelberg: Carl Winter.

Wachter, Rudolf. 1987. Altlateinische Inschriften. Bern \& New York: Peter Lang.

Wallace, Rex E. 1985. "Volscian sistiatiens". Glotta 63.93-101.

Wallace, Rex E. \& Brian D. Joseph. 1991. "On the Problematic $f / h$ Variation in Faliscan". Glotta 69.84-93.

Watkins, Calvert. 1966. "Italo-Celtic Revisted". Ancient Indo-European Dialects ed. by Heinrich Birnbaum \& Jan Puhvel, 29-50. Berkeley and Los Angeles: University of California Press.

-------. 1969. Indogermanische Grammatik. Vol. III: Geschichte der indogermanischen Verbalflexion. Heidelberg: Carl Winter.

\section{SUMMARY}

Faliscan clearly shows affinities with Latin, but the exact nature of the relationship between the two languages has not met with complete acceptance. Some scholars treat Faliscan as nothing more than a 'rural dialect' of Latin, though the inexactness of the designation "dialectal Latin" makes this characterization problematic. Moreover, it is demonstrated here that the various features that are claimed to link Faliscan and non-Roman Latin to the exclusion of the Latin of the city of Rome are all rather late in their appearance in Faliscan, while a few very early features are to be found that unite Faliscan with all of Latinity . At the same time, though, there are significant isoglosses separating Faliscan from all Latin dialects, Roman and non-Roman. The conclusion to be drawn is that Faliscan is a separate language from Latin and not a dialect of Latin, though it is closest sibling to Latin in the Italic family tree.

\section{RÉSUMÉ}


La question de la relation entre latin et falisque s'examine ici en la lumière de la methodologie comparative et la modèle dialectologique de 'Stammbaum'. Il a montré que le falisque n'est pas un dialect rurale de latin, comme ont proposé plusieurs récemment, à cause de trois faits: bien des characteristiques qui se trouvent dans les deux langues n'apparaient que tres tard dans la tradition falisque; il y a aussi des vieux innovations qui unifient les deux; et il y a des isoglosses qui séparent le falisque de tous les dialectes latins--ceux de Rome même que ceux d'ailleurs. Le falisque est une langue liée à latin mais à la même fois pas equivalent à les vrais dialectiques latins.

\section{ZUSAMMENFASSUNG}

In diesem Artikel wird das Verhältnis des Lateinischen mit dem Faliskischen untersucht. Wir beweisen, dass das Faliskische keine lateinische Mundart ist aus den folgenden drei Gründen. Erstens, erscheinen viele Eigenschaften, die sich in beiden Sprachen finden lassen, erscheinen sehr spät im Faliskischen. Zweitens gibt es sehr alte Neuerungen die beide Sprachen gemeinsam haben, und drittens gibt es einige Neuerungen im Faliskischen, die es von allen lateinischen Mundarten, sowohl solchen innerhalb als auch ausserhalb Roms, abtrennen. Das Faliskische ist eine Sprache, die einerseits mit dem Lateinischen verwandt, aber andererseits auch von ihm abgesetzt ist. 